\title{
Den nye beredskapslovgivning i Norge ${ }^{1}$ ).
}

Av høyesterettsdommer H. BAHR.

I.

Forberedelscn av lovene.

Våren 1948 - etter kupet i Tsjekkoslovakia — tok Justisdepartementet opp til behandling sp $\varnothing$ rsmålet om å utbygge og føre à jour den lovgivning under departementet som er gitt med henblikk på krigsog krisetider. Utgangspunktet var det kompleks av lovregler som ble utferdiget under og etter siste krig, for en vesentlig del $\mathrm{i}$ form av provisoriske anordninger.

Forberedelsen av den nye beredskapslovgivning ble i første omgang overlatt til sakkyndige utvalg som departementet oppnevnte.

Det ble overdratt til høyesterettsdommer Reidar Skau og professor Johs. Andenæs å forberede en revisjon av straffebestemmelsene om forbrytelser mot statens selvstendighet og sikkerhet og mot Norges statsforfatning og statsoverhode (straffelovens kapitler 8 og 9 , jfr. landssvikloven av 21 februar 1947 og den midlertidige lov av 13 desember 1946 om bruk av dødsstraff). Utvalget avga innstilling 26 juli 1948. Saken ble så behandlet av straffelovkomitéen under ledelse av nå avdøde høyesterettsdommer Solem. Komitéens uttalelse ble avgitt 18 oktober $1948 .^{2}$ )

Høyesterettsdommer Sverre Grette og høyesterettsadvokat Erik Poulsson fikk i oppdrag å utarbeide forslag til lover om forbud mot forbindelse med fienden og om behandlingen av fiendtlig eiendom. Utvalget avga innstilling 7 juli $1948 .^{3}$ )

Et tredje utvalg - «krigslovutvalget» - bestående av oberst Aage Pran, byråsjef (nå sorenskriver) Olav Svendsen, byråsjef Carl Stabel og forfatteren av denne artikkel, fikk den oppgave å utarbeide forslag til lov om krigstilstand og regler om fengsling, beslag o. l. under krig eller kriseforhold. Som særskilt tilkalte medlemmer av utvalget deltok riksadvokat Andr. Aulie under arbeidet med reglene om forræderisaker og andre spørsmål vedkommende strafferettspleien og professor Frede Castberg under behandlingen av spørsmålet om alminnelige fullmakter

1) Artikkelen, som desverre kom for sent til å komme med i forrige hefte, er utarbeidet av høyesterettsdommer Bahr på grunnlag av regjeringsforslagene. Resultatet av sakens behandling er innarbeidet i teksten av professor Johs. Andenæs.

2) Utyalgets innstilling Red. Ot.prp. nr. $79-1950$.

3) Innstillingen er inntatt i Ot.prp. nr. 80-1950. 
for Kongen og andre administrative organer. Utvalget avga innstilling 25 mars 1950.4 )

En særskilt komité er i gang med å utarbeide forslag til en alminnelig sivilforsvarslov med bestemmelser om sivilforsvarets virksomhet i krig og fred.

Da Korea-krigen hadde pågått en tid, fant Regjeringen det nødvendig å legge frem forslag for Stortinget om store ekstraordinære bevilgninger til militære og sivile beredskapstiltak. Samtidig ble det fremmet forslag til lover om de emner som var behandlet av de tre sakkyndige utvalg. Etter tilråding av Justisdepartementet ble det i statsråd 25 august 1950 besluttet fremsatt følgende lovproposisjoner:

Otprp. nr. $78^{5}$ ) om (1) lov om særlige rådgjerder under krig, krigsfare og lignende forhold - nedenfor kalt «krigsloven» - og (2) lov om kontroll med post- og telegrafforsendelser av 24. juni 1915.

Ot.prp. nr. 79 om lov om endringer i straffelovens kap. 8 og $9 \mathrm{~m}$. v.

Ot.prp. nr. $80 \mathrm{om}$ (1) lov om forbud mot forbindelse med fienden og

(2) lov om fiendtlig eiendom. Denne proposisjon forbigås her.

Behandlingen i Stortingets justiskomité førte til visse endringer i forslaget til revisjon av straffeloven, og formelt sett til en hel omarbeidelse av utkastet til krigslov. ${ }^{6}$ ) De viktigste avvikelser mellom regjeringens forslag og de vedtatte lover vil fremgå av den etterfølgende fremstilling. Lovene er datert 15 desember 1950.

II.

Endringer $i$ straffelovens kap. 8 og $9 \mathrm{~m} . v$.

1. Behovet for en lovrevisjon.

Det sakkyndige utvalg (Skau og Andenæs) som har forberedt endringene i straffeloven, uttaler om behovet for en revisjon av forræderilovgivningen (Ot.prp. nr. 79 s. 4):

»Det er naturlig at straffelovgivningen om landsforræderi og høyforræderi blir tatt op til revisjon på grunnlag av erfaringene under og etter den siste krig. Den moderne krigføring har antatt former som ikke var til å forutse da den alminnelige og den militære straffelov ble gitt i 1902 - med lynoverfall, flyangrep, partisankrig, fallskjerm-

4) Innstillingen er inntatt i Ot.prp. nr. $78-1950$.

5) Et tillegg til denne proposisjon - Ot.meld. nr. 1 for $1950-$ inneholder fyldige opplysninger om krigs- og unntakslovgivning i Storbritannia, Nederland, Belgia, Sveits, Danmark, Finnland og Sverige. Dessuten inneholder den uttalelser fra politimesteren i Oslo, Forsvarsdepartementet og Utenriksdepartementet om forslaget til krigslov.

6) Innstillingen om endringene i straffeloven er Innst. O. XVI 1950, innstillingen om krigsloven Innst. O. XV 1950. Som dok. nr. 111950 er trykt betenkninger fra professorene Castberg og Andenæs om de konstitusjonelle sider ved krigsloven, videre en betenkning om samme lov fra et utvalg nedsatt av Den Norske Sakf $\phi r e r f o r e n i n g$, samt enkelte andre dokumenter. 
tropper, organisert femtekolonnevirksomhet og andre karakteristiske trekk som skiller den moderne totale krig fra eldre tiders mer statiske og begrensede militære styrkeprøver. Det er ikke å vente at de gamle straffebestemmelser som er utformet $\mathbf{i}$ en stabil fredsperiode på bakgrunn av erfaringene fra tidligere kriger, på alle punkter skal svare til de behov som denne omlegning av krigsmetodene har skapt. Det viste seg under den siste krig at Regjeringen fant det nødvendig å supplere de gjeldende bestemmelser med en serie provisoriske anordninger; vi nevner især de forskjellige anordninger om dødsstraff, anordningen av 22. januar 1942 som rettet seg mot medlemskap i N. S. og liknende forhold, og til slutt landssvikanordningen av 15. desember 1944. Av mange grunner vil det være heldig om de n $\varnothing$ dvendige bestemmelser for det tilfelle at vi skulle komme opp i en ny krigssituasjon, kan foreligge på forhånd.»

\section{Rammen for revisjonsarbeidet.}

Både utvalget og departementet understreker at det dreier seg om en provisorisk revisjon med sikte på å avhjelpe de mest åpenbare mangler i forræderilovgivningen for tilfelle av at en plutselig skulle komme opp $\mathrm{i}$ en uforutsett situasjon. Revisjonen nu tar ikke sikte på å overflødiggjøre den inngående revisjon av straffelovens kapitler $8 \mathrm{og}$ 9 som er ført opp på Straffelovkomitéens arbeidsprogram; det har også vært forutsatt at den militære straffelov skal tas opp til grundig revisjon senere.

Til tross for arbeidets provisoriske karakter er loven ikke betegnet som midlertidig, og gyldigheten av loven er ikke knyttet til noen bestemt tidsfrist, noe som også åpenbart ville være upraktisk. Revisjonen er stort sett begrenset til den almindelige straffelov, men det er også foreslått enkelte mindre endringer i den militære straffelov.

3. Området for straffbarhet.

a. Straffelovens kap. $8 .^{7}$ )

Det sentrale straffebud i kap. 8 er $\$ 86$. Det er denne bestemmelse som har dannet hovedgrunnlaget for rettsoppgjøret etter okkupasjonen. I den tidligere lov var straffetrusselen rettet mot «den, som rettsstridig bærer vaaben mot Norge, eller som under en krig, hvori Norge deltager, eller med saadan krig for $\varnothing \mathbf{i e}$, yder fienden bistand i raad eller daad eller svækker Norges eller nogen med Norge forbunden stats stridsevne.»

7) Stort sett kan det sies at kap. 8 inneholder bestemmelser om de forbrytelser som i daglig tale sammenfattes under betegnelsen »landsforræderi«, mens kap. 9 handler om »h $\phi$ yforræderi«. Men sondringen er ikke gjennomf $\varnothing \mathrm{rt}$ konsekvent ved fordelingen av stoffet mellom de to kapitler. Straffeloven selv bruker ikke uttrykkene landsforræderi og høyforræderi. 
I den nye formulering er den generelle straffetrussel beholdt, men for å gjøre bestemmelsen mer anskuelig er de viktigste forræderiformer spesifisert i paragrafen i 9 særskilte punkter. Oppregningen er ikke uttømmende. Forræderihandlinger som ikke går inn under noen av de andre punkter $\mathrm{i}$ oppregningen, vil rammes av sekkebestemmelsen i $\mathrm{nr} .10$, som med visse endringer svarer til den nåværende $\S 86$.

Lovens \& 86 lyder etter revisjonen slik:

Med fengsel fra 3 âr inntil på livstid straffes den som i krigstid eller med krigstid for $\varnothing$ ye

1) bærer våpen mot eller på annen måte deltar i militære operasjoner mot Norge,

2) skaffer fienden opplysninger til bruk ved slike operasjoner,

3) svekker Norges motstandsevne ved å $\phi$ delegge, skade eller sette ut av bruk anlegg eller gjenstander av betydning for rikets krigsinnsats,

4) opphisser eller forleder til troløshet, driver propagandavirksomhet for fienden eller utbrer uriktige eller villedende opplysninger som er egnet til å svekke folkets motstandsvilje,

5) stifter, går inn $i$, deltar aktivt $i$ eller yter $\emptyset$ konomisk st $\varnothing t t e$ av betydning til parti eller organisasjon som virker til fordel for fienden,

6) medvirker ved angiveri eller på lignende måte til at noen blir utsatt for frihetsberøvelse eller annen overlast av fienden eller parti eller organisasjon som nevnt under nr. 5

7) oppfordrer eller tilskynder til, er med på beslutning om eller deltar i lockout, streik eller boikott som er ulovlig etter arbeids- eller boikottlovgivningen og som svekker Norges motstandsevne,

8) deltar på utilbørlig måte i fiendens administrasjon av okkupert norsk område,

9) utfører eller deltar på utilbørlig måte i ervervsvirksomhet for fienden,

10) på annen mâte rettsstridig yter fienden bistand mot Norge eller svekker Norges motstandskraft,

eller som medvirker hertil. Var det straffbare forhold av underordnet betydning, kan straffen settes til fengsel under 3 år. På samme måte straffes den som foretar slik handling mot en stat som er i forbund med Norge eller i krig med en felles fiende.

Det som her er bestemt gjelder også såfremt handlingen er foretatt når det er innledet militære kamphandlinger mot Norge eller fors $\phi \mathbf{k}$ fra fremmed makt på å besette eller angripe norsk område eller med slike forhold for $\varnothing$ ye.

Straff kommer ikke til anvendelse på noen i utlandet bosatt norsk statsborger for handling som han etter bostedets lover er pliktig til.

Som det vil sees, er lovens tidligere uttrykk: «under en krig, hvori Norge deltar» erstattet med: «i krigstid». «Krigstid» i straffelovens forstand kan inntre allerede ved en alminnelig eller delvis mobilisering, jfr. lovens $\& 8$.

Det sakkyndige utvalg uttaler (prp. s. 5-6) at en ved den foretatte endring «... oppnår ... den lettelse for rettshåndhevelsen at spionasje og forsvarssabotasje som er foretatt i en slik situasjon, blir å bed $\varnothing \mathrm{m}$ me etter de strengere bestemmelser i $\S 86$ uten at det er nødvendig å bevise at den har funnet sted «med krig for $\varnothing$ ye». Blir det utferdiget 
en særskilt lov om krigstilstand, vil bestemmelsen også kunne suppleres av vedtak om krigstilstand med hjemmel i en slik lov . . . Dette stemmer med ordningen i den svenske lov, kap. $27 \S 16$. Utvalget har imidlertid funnet at en b $\emptyset \mathbf{r}$ gå et skritt videre. Erfaring viser at en nå må regne med uventede lynangrep hvor angriperne erklærer å komme som venner og med bistand innenfor landets grenser fra organiserte grupper av agenter og sympatis $\varnothing \mathrm{rer}$ som fors $\varnothing$ ker å tåkelegge situasjonen, kanskje også ved et kup å sette de lovlige myndigheter ut av spillet og innsette en ny regjering $\mathrm{i}$ forståelse med angriperstaten. Det kan under slike forhold inntre situasjoner hvor det ikke uten videre er klart om landet er i krig eller ikke, og hvor Regjeringen ennå ikke har fått klargjort situasjonen ved beslutning om mobilisering eller erklæring om krigstilstand. Det kan også tenkes at det som begynner som en n $\varnothing$ ytralitetskrenkelse eller som en skuddveksling mellom grensetropper, kan gripe om seg og ende som regulær krig, uten at det er lett å fiksere overgangen. Nettopp i den kritiske åpningsfase av krigen er det viktig at det ikke kan herske noen uklarhet. Det er derfor i utkastet gjort fors $\varnothing \mathrm{k}$ på å forme en regel som dekker alle påkommende tilfelle.» Disse overveielser har f $\varnothing \mathrm{rt}$ til bestemmelsen i paragrafens 2. ledd. Den lovtekniske formulering av bestemmelsen skyldes vesentlig straffelovkomitéen. Bestemmelsen vil få betydning i tilfelle hvor Regjeringen på en eller annen måte blir satt ut av spillet.

Med hensyn til oppregningen av forræderihandlinger vil det sees at nr. 1 - «bærer våpen mot eller på annen måte deltar i militære operasjoner mot Norge» - opptar første alternativ i den tidligere $\S 86$ 's gjerningsbeskrivelse. Av de $\emptyset$ vrige punkter er det en rekke som tydelig avspeiler erfaringene fra rettsoppgj $\phi$ ret, se særlig nr. 5, 6, 8 og 9 .

Proposisjonens bestemmelse om ulovlig streik og lockout (nr. 7 i loven), var gjenstand for sterke angrep fra Arbeidernes Faglige Landsorganisasjon og ga grumnlag for voldsom agitasjon fra kommunistisk hold mot dette «angrep på streikeretten». Den formulering som bestemmelsen har fått $\mathrm{i}$ loven, ble imidlertid godtatt av Landsorganisasjonen.

Den tidligere bestemmelse nevnte ikke medvirkning. Dette har hatt liten betydning under rettsoppgjøret fordi uttrykket «bistand til fienden» er så omfattende. ${ }^{8}$ ) Om det samme gjelder for alternativet svekkelse av motstandskraften, er ikke klart. I den nye lov er medvirkning tatt med i straffetruselen.

Etter en ny $\S 86$ a straffes den som grovt uaktsomt forgår seg som nevnt i $\S 86$, med hefte eller fengsel inntil 5 år. Det ville vært en lettelse for domstolene om man hadde hatt en slik bestemmelse under landssvikoppgjøret. Den gjeldende $\S 86$ rammer overhodet ikke uaktsom overtredelse.

I $\S 86 \mathrm{~b}$ inneholder loven en ny bestemmelse som er inspirert av erfaringene fra Danmark under siste krig. Den er rettet mot utilb $\phi$ rlig.

8) Jfr. Retst. 1945 s. 16. 
samarbeid med okkupasjonsmakten under en påtvunget besettelse uten krigstilstand. Paragrafen lyder:

«Den som uten at forholdet går inn under $\$ 86$, under en påtvunget besettelse av norsk område yter okkupasjonsmakten en åpenbart utilb $\varnothing$ rlig bistand, eller som medvirker hertil, straffes med fengsel.

Har handlingen hatt til følge stor skade for landet eller noens $\mathrm{d} \phi \mathrm{d}$, betydelig skade på legeme eller helbred, store lidelser eller langvarig frihetsber $\varnothing v e l s e$, kan fengsel på livstid anvendes.»

Foruten i tilfelle hvor Regjeringen finner å måtte bøye seg for et krav om besettelse uten å ta krig, vil bestemmelsen kunne få anvendelse f. eks. hvis det lykkes ved et lynoverfall å sette landets lovlige myndigheter helt ut av spillet, slik at det hverken kan bli tale om motstand eller mobilisering. Det kan også tenkes at landet under en storkrig blir påtvunget en okkupasjon av en makt som det i og for seg har interesse av å støtte fordi de to lands interesser i utfallet av krigen faller sammen. Bestemmelsen gjelder også en okkupasjonssituasjon av denne art. Utvalget bemerker (prp. s. 12) at det under enhver okkupasjon, uansett hvor vennligsinnet okkupasjonsmakten er, vil være en opgave for norske myndigheter og norske borgere så langt som mulig å hevde den nasjonale handlefrihet og nasjonale interesser ellers overfor okkupasjonsmakten. Den som går denne makts ærender på anstøtelig måte, må være forberedt på et senere oppgjør.

\$ 97 inneholder en ny bestemmelse som vil ramme utilbørlig utnyttelse av forholdene under en okkupasjon selv om forholdet ikke innebærer bistand til fienden. Under rettsoppgjøret har man følt savnet av en slik bestemmelse. Bestemmelsen gjelder både den vanlige krigerske okkupasjon og den «fredelige» form for okkupasjon som omhandles i $\S 86 \mathrm{~b}$.

Av endringer som ellers er foretatt i kap. 8, nevner jeg: Bestemmelsen i \& 94 som er rettet mot visse former for forberedelse til forræaeri, er noe utvidet. Dessuten er etter forbilde av den svenske lov tatt opp enkelte bestemmelser mot en virksomhet som indirekte kan bety en fare for rikets selvstendighet eller den indre fred. $\S 97$ a setter straff for den nordmann som av fremmed makt eller parti eller organisasjon som opptrer i dens interesse, mottar $\phi$ konomisk st $\varnothing$ tte for å påvirke almenhetens mening om statens styreform eller utenrikspolitikk eller til partiformål. $\S 97 \mathrm{~b}$ retter seg mot visse former for samfunnsfarlig ryktespredning. I $\S 95$ annet ledd er gitt en regel om beskyttelse for fremmede makters representanter mot forulempning.

b. Straffelovens kap. 9 .

Hovedbestemmelsen i dette kapitel er $\S 96$ : «Den, som søger at medvirke til, at rigets statsforfatning ved ulovlige midler forandres, straffes med hefte $i$ mindst 5 år.» Paragrafen har vært anvendt $i$ en del saker under rettsoppgjøret - ved siden av $\$ 86$ - men har neppe hatt noen 
større betydning ved straffeutmålingen. Gjerningsbeskrivelsen i paragrafen er ikke endret ved lovrevisjonen.

Høyesterett har antatt at $\S 98$ bare rammer den som s $\varnothing$ ker med ulovlige midler å forandre de konstitusjonelle organers oppbygning og virkemåte, og ikke omfatter f. eks. endringer i det kommunale styresett; jfr. Retst. 1945 s. 187 . For å skape et vern mot slike høyforræderske anslag også når de ikke er rettet mot selve forfatningen, er det $\mathrm{i}$ den nye lov tatt inn to nye straffebud: $\S 97$ og $\S 99$ a. Den førstnevnte paragraf er plasert i kap. 8 og er behandlet foran under a. Den skal gjelde under okkupasjon. Med henblikk på lignende angrep i krigs- eller krisetider, men utenfor okkupasjonstilfelle, er det i § 99 a fastsatt straff for den som «med bruk av våpenmakt eller under utnyttelse av frykt for inngripen av fremmed makt hindrer offentlige myndigheter i deres virksomhet, eller foretar alvorlige overgrep mot offentlige tjenestemenn, pressen, foreninger eller institusjoner eller for $\emptyset$ vrig setter betydelige samfunnsinteresser i fare, eller som medvirker hertil.»

Til disse bestemmelser bemerker departementet bl. a. (prp. s. 34) :

«Erfaringene fra krigstiden har . . . . vist at den någjeldende bestemmelse i strl. § 98 ikke strekker til under forhold som kan oppstå når landet er okkupert av en fremmed makt. Selv om det,ikke egentlig dreier seg om angrep på forfatningen, kan politiske fraksjoner nytte leiligheten til å søke gennomf $\phi$ rt endringer i grunnleggende deler av den gjeldende rettsorden med uttrykkelig eller stilltiende samtykke fra okkupasjonsmakten. Nyordningen av kommunestyret i Norge i medhold av det nazistiske innenriksdepartements forordning af 21 . desember 1940 er et eksempel på dette. Begivenhetene i etterkrigstiden har gitt anledning til å anta at lignende situasjoner kan melde seg også utenfor okkupasjonstilfeller når et land blir hjems $\phi k t$ av dyptgående politiske kriser.»

Som ny $\S 104$ a er tatt inn en bestemmelse om straff for å danne eller delta i private militærorganisasjoner.

\section{c. Åpenbaring av statshemmeligheter.}

Etter forslag av det sakkyndige utvalg tar departementet i proposisjonen opp til behandling et spørsmål som tidligere to ganger har vært forelagt for Stortinget uten resultat, nemlig spørsmålet om straff for aipenbaring av statshemmeligheter.

Etter gjeldende lov kan en offentlig tjenestemann som røper tjenestehemmeligheter, i alminnelighet straffes. Men mot dem som i skrift eller tale bringer opplysningene videre, kan det som hovedregel ikke reageres med straff. Proposisjonen foreslo en ny bestemmelse herom i $\S 130$. Senere har imidlertid justisministeren etter henstilling fra Presseforbundet gått med på at spørsmålet om endringer i § 130 utsettes. Dette skal nå utredes av straffelovkomitéen i forbindelse med 
sp $\varnothing$ rsmålet om nye lovregler om pressens $\phi$ konomiske og strafferettslige ansvar i sin alminnelighet. ${ }^{9}$ )

\section{Straffene.}

Av de foretatte endringer i straffarter og straffesatser skal jeg her bare behandle sp $\emptyset$ rsmålet om d $\varnothing$ dsstraffen.

Ved straffeloven av 1902 ble d $\varnothing$ dsstraffen fjernet fra den alminnelige straffelovgivning. Men den ble opprettholdt for krigstid ved den militære straffelov, som ble vedtatt samtidig. Den militære straffelov hjemler d $\varnothing$ dsstraff for krigsforræderi og en del andre forbrytelser mot krigsartiklene. ${ }^{10}$ ) Loven gjelder f $\varnothing$ rst og fremst for militærpersoner og andre som er knyttet til den vepnede makt, og for krigsfanger. Men krigsartiklene kan også anvendes mot sivilpersoner som forbryter seg på krigsskueplassen. ${ }^{11}$ )

Dessuten inneholdt lov av 5. februar 1932 om straff for handlinger som påtales ved riksrett, hjemmel for å id $\varnothing m m e$ statsråder og stortingsmenn d $\varnothing$ dsstraff for forbrytelser i krigstid mot straffelovens $\S \S$ 83,84 og $86 .{ }^{12}$ )

Denne avgrensning av området for d $\varnothing$ dsstraff svarer ikke lenger til nåtidens forhold. I innst. O.nr. 265-1946 heter det herom:

«I 1902 da den militære straffelov ble utformet, var krigf $\varnothing$ ringen relativt statisk og lokalt begrenset til bestemte områder. Når loven ville beholde adgangen til å anvende dødsstraff overfor krigsforræderi, var det derfor rimelig at man begrenset regelen til å gjelde handlinger begått "på krigsskueplassen». Senere er forholdene imidlertid blitt radikalt forandret. For det første har den moderne krigføring gjennom luftkrigen og ved operasjoner av fallskjermssoldater, commandosavdelinger, partisaner og sabot $\varnothing$ rer i okkuperte distrikter m. v. faktisk utvidet og sprengt det strategiske begrep «krigsskueplassen «. For det annet er helt nye kampmidler tatt i bruk som f. eks. oppløsning av motstanderens kampmoral gjennom psykologisk krigføring, femtekolonnevirksomhet, organisasjon av provokasjon og angiveri $\mathrm{m}$. v. Handlinger av denne art er ikke knyttet til «krigsskueplassen» når dette ord tas i sin snevreste betydning, men de representerer ikke desto mindre nettopp en innsats av den art den militære straffelovs $\S 80$ jfr. $\S 9,5$ har ment å ramme med dødsstraff.»

9) I mellemtiden har man fått en demonstrasjon av dette hull i loven, idet en privatmann, overlege Scharffenberg, under titelen "Norske aktstykker til okkupasjonstidens historie ", har offentliggjort en rekke referater fra hemmelige stortingsm $\varnothing$ ter, som er kommet i hans besittelse.

10) Se lovens $\S \S 80,87,88,90-92,96,97,101,102$ og 107.

11) Se lovens $\$ 9 \mathrm{nr}$. 5, slik bestemmelsen lød før lovendringen av 15. desember 1950.

12) Denne bestemmelse er opphevet ved den nye lov. Statsråder og stortingsmenn kommer nå inn under de vanlige regler i strl. kap. 8 og 9 . 
Under krigen fant Regjeringen det nødvendig å utvide adgangen til bruk av dødsstraff, og dens anordninger om dette ble etter frigjøringen stadfestet av Stortinget, senest ved midlertidig lov om bruk av dødsstraff av 13 desember 1946.

Det sakkyndige utvalg fant at dødsstraff utvilsomt er nødvendig under krig, og at adgangen til å bruke d $\varnothing$ dsstraff ikke kan begrenses strengt til handlinger som er begått under krigen. I utvalgets bemerkninger heter det bl. a. (prp. s. 7):

«En forræderihandling som er begått umiddelbart f $\varnothing \mathbf{r}$ krigsutbruddet kan være like skammelig og like farlig som en tilsvarende handling under selve krigen. Vi kan f. eks. tenke oss at en organisasjon, som står i ledtog med en fremmed makt, ved et attentat rydder konge og regjering av veien for å skape forvirring og dermed bane veien for et angrep, eller at det nettopp i timene f $\varnothing \mathrm{r}$ angrepet setter inn foretas omfattende sabotasje overfor kringkasting, telefon og telegraf for å hindre en rask mobilisering.

Det har vært inngående drøftet i utvalget om det ikke kunne la seg gjøre å gjennomføre en ordning slik at id $\varnothing$ mmelse og fullbyrdelse av d $\varnothing$ dsstraff bare kan finne sted $\mathrm{i}$ den tid riket er i krig, mens handlingen kan være begått tidligere, slik som det er gjort $\mathrm{i}$ den svenske «lag om dödsstraff $\mathrm{i}$ vissa fall då riket är i krig», jfr. også tanken i mil. strl. § 14.13) En måtte under enhver omstendighet gjøre unntak for det tilfelle at rettsapparatet har vært satt ut av funksjon på grunn av okkupasjonen; hermed synes det naturlig å likestille det tilfelle at forfølgning har vært utelukket fordi gjerningsmannen har oppholdt seg på fiendtlig territorium.

Etter nærmere drøftelse har en imidlertid forlatt tanken. Det er ikke til å unngå at enhver avgrensning etter faste kriterier kommer til å virke $\mathrm{i}$ noen grad vilkårlig, slik at en ofte vil ha vanskelig for å peke på noen rimelig grunn til at dødsstraff skal være tillatt $i$ ett tilfelle, men utelukket $\mathrm{i}$ et annet som kanskje er vel så grovt. Utvalget er under atskillig tvil blitt stående ved at hele spørsmålet får overlates til avgjørelse ved domstolenes straffeutmåling, benådningsmyndighetenes praksis og eventuell amnestilovgivning etter krigens opph $\phi \mathbf{r} \ldots \ldots$. .

Både straffelovkomitéen og departementet drøfter spørsmålet inngående, og er blitt stående ved å slutte seg til utvalgets oppfatning. Om d $\varnothing$ dsstraff for overtredelse af $\S 98$ (oppr $\varnothing r$ r) uttaler straffelovkomitéen:

»Hvis opprørerne griper til våpen for å gjennomf $\varnothing$ re sine planer, kan det lett utvikle seg til en alminnelig borgerkrig. Situasjonen kan bli vel så kritisk som under krig med et annet land. Særlig vil dette være tilfelle dersom et vepnet opprør blir satt i gang når den utenrikspo-

13) Den militære straffelovs $\S 14$ bestemte: «D $\phi$ dsstraff kan kun anvendes i Krigstid, dog ikke efter Krigens Oph $\phi r$. . .» Denne regel ble opphevet ved den nye lov. 
litiske situasjon er på bristepunktet, eller når det raser en krig som Norge ikke deltar i. Såfremt opprøret ikke straks blir slått ned, kan det lett lede til at en fremmed makt griper inn. Det kan $i$ et sådant tilfelle oppstå en situasjon hvor det er grunn til å anta at anvendelse av d $\varnothing$ dsstraff mot en opprørsleder er det eneste som kan vekke andre til besinnelse og derved skaffe de lovlige myndigheter herred $\varnothing \mathrm{mme}$ over situasjonen. Komitéen antar også at allerede den omstendighet at det er foreskrevet dødsstraff for slike handlinger, vil kunne få en stor preventiv betydning.

Komitéen mener at nettopp når man ser hen til at det gjelder å verge samfunnet $\mathrm{i}$ den ytterste $n \emptyset \mathrm{d}$, kan bruk av d $\varnothing \mathrm{d}$ sstraff $\mathrm{i}$ slike tilfelle som her er nevnt, være mer påkrevet enn den er under et oppgjør med forræderne etter en fiendtlig okkupasjon.»

I motsetning til den nylig vedtatte svenske lov om «dödsstraff i vissa fall då riket er i krig» av 30. juni 1948 var i proposisjonen d $\varnothing$ dsstraff innført som et alternativ i vedkommende paragrafer i den alminnelige straffelov. Begrunnelsen for den svenske ordning er at man vil »understryka detta straffs extraordinära karaktär«.24) Det sakkyndige utvalg fant ikke denne begrunnelse avgjørende. Når en først har bestemmelser for krigstilfelle $\mathrm{i}$ den alminnelige straffelov, burde en etter utvalgets mening også ha den virkelige strafferamme der, ikke en fiktiv strafferamme som korrigeres ved en særskilt lov. Særlig gjelder dette når en som utvalget - til forskjell fra den svenske lov ikke prinsipielt vil begrense id $\varnothing$ mmelse og fullbyrdelse av d $\varnothing$ dsstraff til den tid da riket er i krig. (Prp. s. 8.)

På dette punkt gikk imidlertid justiskomitéen med tilslutning av Stortinget en annen vei, idet komitéen f $\varnothing$ rte bestemmelsene om d $\phi \mathrm{ds}$ straff over til den militære straffelov $\mathrm{i}$ en ny $\S 81 \mathrm{a}$. Begrunnelsen var at «den alminnelige borgerlige straffelov til enhver tid bør omfatte de rettsregler og de straffearter som vi godtar som et ledd $i$ den normale bekjempelse av kriminaliteten. Hvis vi allikevel som en nødsforanstaltning, og i rent selvforsvar, kan bli tvunget til å gripe til straffereaksjoner som vi ellers aldri ville bruke, så bør reglenes rent ekstraordinære karakter også finne sitt uttrykk i deres lovtekniske utformning og plasering». (Innst. O. XVI - 1950 s. 2). Området for dødsstraffen ble også noe innskrenket i forhold til proposisjonen. Den ble begrenset til å gjelde overtredelse av den borgerlige straffelovs $\$ \S 83$, 86, 98 eller 99, og den nye bestemmelse i militære strl. $\S 81$ a er utformet med sikte på å gjøre det klart at dødsstraff utenfor krigstid bare kan komme til anvendelse i en krigslignende situasjon.

Under den offentlige debatt om proposisjonen var det atskillig motstand mot dens utvidelse av området for dødsstraff. De endringer som justiskomitéen foretok bidro til å ta brodden av disse angrep, og ved behandlingen i Stortinget var det bare en beskjeden minoritet - $20 \mathrm{i}$

14) Första lagutskottets utlåtande nr. 39 for 1948, s. 44. 
Odelstinget 9 i Lagtinget - som stemte imot. Et forslag om at d $\varnothing \mathrm{ds}$ straff som ikke er eksekvert $f \varnothing r$ krigens slutt, går over til livsvarig fengsel, ble imidlertid forkastet med temmelig knepent flertall.

\section{III.}

ot. prp. nr. 78 .

1. Lov om særlige rådgjerder under krig, krigsfare og lignende forhold - krigsloven.

a. Tidligere forslag og bestemmelser.

Tanken om en slik lov var fremme flere ganger allerede f $\phi r$ utbruddet av den annen verdenskrig, men uten at det $\mathrm{f} \phi \mathrm{rte}$ til noe. Etter utbruddet av den annen verdenskrig høsten 1939 nedsatte Regjeringen et utvalg under ledelse af nå avdøde fylkesmann Christensen til å utrede saken. Komitéens forslag ble lagt til grunn for en Ot.prp. av 5 . april 1940 om lov om særlige rådgjerder under krig. Proposisjonen rakk ikke frem til behandling $f \phi r$ det tyske overfall, men reglene ble praktisk talt uforandret fremmet som provisorisk anordning den 14. april 1940. Denne anordning, populært kalt krigsanordningen, var med enkelte endringer gjeldende under hele krigen. Med hjemmel i denne anordning ble det bl. a. gitt regler om adgang til forvaring (internering) av folk som var mistenkt for statsfiendtlig virksomhet og - i forbindelse med frigjøringsoperasjonene i Norge - om militær pressekontroll. Alle de nevnte bestemmelser, inklusive krigsanordningen, falt imidlertid bort etter frigjøringen.

\section{b. Bakgrumnen for forslaget.}

Regjeringens lovforslag bygget på den betraktning at det under en eventuell ny krig antakelig vil bli behov for minst like vidtgående bestemmelser som dem vi hadde sist, og at det vil være lite tilfredsstillende om spørsmålet atter skal måtte løses ved provisoriske anordninger utarbeidet $\mathrm{i}$ hast etterhvert som behovet blir presserende. Det stemmer best med demokratiets grunnsetninger at den lovgivende makt utformer Regjeringens n $\emptyset$ dsfullmakter — og det på et tidspunkt hvor det kan skje i full offentlighet og uten at begivenhetenes press gjør seg for sterkt gjeldende. Disse fullmakter kan ikke begrenses til å gjelde bare i situasjoner med åpen, organisert krig. Det må være adgang til å sette i verk adekvate forsvarstiltak mot "femtekolonnevirksomhet «, selv om det hersker «fred» i teknisk-juridisk forstand.

c. Oversikt over innholdet i regjeringens lovforslag.

Forslaget til «krigsloven» inneholder en rekke forskjellige bestemmelser, fordelt på 10 kapitler: I. Vilkårene for lovens anvendelse. II. Forholdet mellom militær og sivil myndighet på krigsskueplass. III. Særregler om behandlingen av straffesaker. IV. Forræderidomstol. V. 
Sikringstiltak. VI. Kontroll med trykte skrifter m. v. VII. Tvangsavståing til det offentlige. VIII. Særlige fullmakter for Kongen. IX. Kongens myndighet når Stortinget på grunn av krig er avskåret fra å ut $\varnothing$ ve sin virksomhet. X. Forskjellige bestemmelser.

For en stor del bygger lovforslaget på regler vi hadde under siste krig. På enkelte punkter er reglene noe utvidet, på andre punkter er det tatt med kauteler som ikke fantes forrige gang.

Det er fire av kapitlene som har vært $\mathrm{i}$ forgrunnen $\mathrm{i}$ den offentlige diskusjon, nemlig de som handler om vilkårene for å anvende loven, om forræderidomstolen, om sikringstiltak og om kontroll med trykte skrifter $\mathrm{m}$. v. Lovens kanskje viktigste avsnitt er imidlertid kapitlene om særlige fullmakter for Kongen og om Kongens myndighet når Stortinget på grunn av krig er avskåret fra å utøve sin virksomhet. Det endelige resultat av lovbehandlingen ble at de mest omstridte kapitler i forslaget gikk ut, idet forutsetningen har vært at Kongen i tilfelle får falle tilbake på de generelle fullmakter. Da den offentlige diskusjon har knyttet seg til proposisjonens bestemmelser, og da kjennskap til disse er nødvendig for en bedømmelse av hva som ligger i de generelle fullmakter, skal jeg imidlertid gi en oversikt over de omstridte bestemmelser.

Kap. I: Vilkårene for å anvende loven.

Etter utkastets $\S 1$ f $\varnothing$ rste ledd kommer lovens bestemmelser uten videre til anvendelse når riket er i krig. Det kreves ikke at det foreligger formell krigserklæring fra den ene eller fra begge parter. Et væpnet angrep mot norsk territorium, fra sjø, over land eller fra luften, vil automatisk utløse lovens anvendelse.

Etter annet ledd skal loven ved særskilt vedtak kunne bringes til anvendelse selv om riket ikke er i krig.. Vilkåret er enten at «krig truer» eller at «rikets selvstendighet eller sikkerhet er i fare som f $\varnothing$ lge av pågående eller truende fiendtligheter mellom fremmede stater eller av andre grunner». Det siste alternativ - også kalt «det tredje vilkår» - forutsetter som man vil se, at rikets selvstendighet eller sikkerhet kan bli truet av andre grunner enn krig, truende krigsfare eller fiendtligheter mellom fremmede stater. Under en situasjon med sterk utenrikspolitisk spenning vil således indre uroligheter kunne bety en overhengende fare for rikets sikkerhet, selv om det i $\varnothing$ yeblikket ikke kan påvises at det foreligger krigsfare for Norge.

Vedtak om at loven skal få anvendelse utenfor krig skal etter utkastet gjøres av Kongen alene. Vedtaket kan gjelde hele loven eller deler av den og kan begrenses til bestemte distrikter. 
Kap. IV: Forræderidomstol.

Bakgrunnen for reglene i dette kapitel er det lovforslag som samtidig ble fremsatt om innføring av dødsstraff for visse forræderiforbrytelser også når de er begått $\mathrm{i}$ fredstid. ${ }^{15}$ ) D $\phi$ dsstraff vil ha liten avskrekkende virkning overfor folk som har solidarisert seg med fienden og som regner med at denne vil være herre $i$ landet f $\phi \mathbf{r}$ en d $\phi$ dsdom kan eksekveres. Vil en derfor bruke d $\phi$ dsstraff som n $\emptyset$ dverge overfor forræderihandlinger, må straffebestemmelsene suppleres med rettergangsregler som åpner adgang til å gjennomf $\varnothing r e$ rettsforf $\varnothing$ lgning og straffullbyrdelse vesentlig raskere enn i vanlige straffesaker.

Krigslovutvalget drøftet bl. a. den mulighet å legge sakene til de militære standretter, men tanken ble forkastet, da hverken standretten eller den militære påtalemyndighet er organisert med sikte på håndhevelse av den borgerlige straffelovs forræderibestemmelser. Utvalget ble stående ved at de særlige hensyn som her gjør. seg gjeldende, best kan realiseres ved at det organiseres en særskilt forræderidomstol sammensatt av 5 embetsdommere på samme måte som en avdeling av Høyesterett.

Forræderidomtolen skal etter forslaget gjøre tjeneste som domstol i f $\varnothing$ rste og siste instans.

Forslaget bygger på at forfølgning ved forræderidomstol bare må finne sted i tilfelle hvor det ikke kan herske rimelig tvil om at tiltalte har begått en handling som kan kvalifisere til d $\emptyset$ dsstraff. Det er derfor oppstilt strenge vilkår for adgangen til at bringe en sak inn for forræderidomstol, formet etter m $\varnothing$ nster av dem som gjelder for adgangen til militær standrettsbehandling (jfr. den militære rettergangslov av 29. mars $1900 \S 233)$. Vilkårene fremgår av utkastets $\S 12$ :

"Saker om forbrytelser mot den borgerlige straffelovs kapitler 8 eller 9 hvor den borgerlige påtalemyndighet vil nedlegge påstand om d $\varnothing$ dsstraff, kan etter beslutning av riksadvokaten bringes inn for forræderidomstol etter reglene i dette kapitel, hvis den mistenkte er grepet på fersk gjerning eller for $\emptyset$ vrig under omstendigheter som ikke synes å levne tvil om hans straffeskyld, og det av hensyn til rikets sikkerhet anses n $\varnothing$ dvendig at den skyldige uten opphold blir straffet.

Bestemmelsen i f $\varnothing$ rste ledd gjelder tilsvarende for saker om forbrytelser mot krigsartiklene $\mathrm{i}$ den militære straffelov når de påtales av den borgerlige påtalemyndighet. «

Utkastet inneholder også bestemmelser om saksbehandlingen ved forræderidomstolen. De er utformet med henblikk på en meget rask gjennomf $\varnothing$ ring av rettergangen. Men samtidig har man $s \varnothing \mathrm{kt}$ å bevare de viktigste av de kauteler straffeprosessloven oppstiller mot uriktig domfellelse. Bestemmelsene er stort sett utformet etter mønster av reglene for den militære standrettsbehandling (den militære rettergangslovs kap. 33).

\footnotetext{
15) Se foran i avsnitt II punkt 4.
} 
Hvis domstolen finner at vilkårene for behandling ved forræderidomstol ikke er til stede, kan den avvise saken uten hovedforhandling. Tiltalte skal alltid ha forsvarer, og forsvareren skal ha full adgang til sakens dokumenter og - selvsagt - rett til å føre motbevis. Dommen skal avsies innen 48 timer, og kan bare gå ut på dødsstraff eller frifinnelse for tiltale ved forræderidomstol. Til dødsdom kreves enstemmighet mellom rettens 5 medlemmer. Når dødsdom er avsagt, skal den som regel straks fullbyrdes. Riksadvokaten kan dog bestemme at fullbyrdelsen skal unnlates eller utsettes. Er fullbyrdelse ikke skjedd innen 24 timer etter domsavsigelsen, bortfaller dommen. En frifinnende avgjørelse vil ikke være til hinder for at sak etterpå blir reist ved de alminnelige straffedomstoler.

Forfølgning ved forræderidomstol vil det utvilsomt bare bli tale om i helt ekstraordinære tilfelle.

Kap. V: Sikringstiltak.

Etter utkastets $\S 25$ skal politiet kunne pågripe folk som med skjellig grunn mistenkes for å ha foretatt eller å være i ferd med å foreta eller å forberede landsforræderi eller andre alvorlige forbrytelser som vil bety en særlig fare for rikets sikkerhet eller selvstendighet, og holde dem i forvaring i inntil 30 dager, uten at straffeprosesslovens regler kommer til anvendelse. Med samtykke av Jutisdepartementet kan forvaringen forlenges også utover denne frist.

Også dette er et middel som bare kan forsvares som ledd i samfundets n $\varnothing$ dverge. Men erfaringen fra siste krig viser at det ble nødvendig å gripe til slike tiltak både i krigførende og ikke krigførende land. Jeg har tidligere nevnt at vi selv hadde regler om forvaring gitt med hjemmel i krigsanordningen af 1940. I Storbritannia gjaldt en ordning som i alt vesentlig svarer til den som nå foreslås her. Etter den kjente Regulation $18 \mathrm{~b}$ kunne myndighetene ta $\mathrm{i}$ forvaring ikke bare personer som med skjellig grunn ble mistenkt for å væere i ferd med eller å forberede noen slik forbrytelse som er nevnt $i$ vårt lovforslag, men også personer som var eller hadde vært medlemmer av organisasjoner som var underkastet fremmed kontroll eller innflytelse, eller av organisasjoner hvis ledere sto $\mathrm{i}$ forbindelse med eller hadde gitt uttrykk for sympati med regjeringssystemet i en fiendtlig stat. Denne siste bestemmelse tok sikte på medlemmer av British Union of Fascists. Så sent som ved utgangen av 1943, da forholdene i Storbritannia var temmelig avklaret på den indre front, hadde man vel 300 personer i forvaring etter disse bestemmelser. I det nøytrale Sverige kumne etter en lov av 9. januar 1940 lignende regler anvendes overfor utlendinger, ja for kortere tid også overfor landets egne borgere, når de var mistenkt for stats- eller forsvarsfiendtlig virksomhet. Vurderin- 
gen av tiltakets nødvendighet tillå administrasjonen og kunne ikke prøves av domstolene. ${ }^{16}$ )

Reglene i proposisjonen går i det vesentlige ut på det samme som bestemmelsene av 1940 i den skikkelse de fikk ved den såkaldte «politianordning» av 1943. Men det er innført et meget betydningsfuldt kautel som ikke gjaldt dengang. Etter forslaget skal det nemlig oppnevnes et råd på 5 medlemmer til å gjøre tjeneste som rådgiver for departementet i forvaringssaker. Medlemmene skal dels oppnevnes av Stortinget, dels av Kongen. Skal noen holdes i forvaring ut over 3 måneder, må spørsmålet innen utløpet av denne frist forelegges for rådet, som har rett og plikt til å granske saken, om nødvendig gjennom rettslig eller utenrettslig etterforskning. Den som holdes i forvaring, har rett til å uttale seg overfor rådet. Spфrsmålet om fortsatt forvaring skal prøves av rådet hver sjette måned. Et annet kautel ligger $i$ at departementet hver tredje måned skal utarbeide en melding om forvaringer som er opprettholdt ut over 3 måneder. Meldingen skal snarest mulig forelegges for Stortinget.

Kap. VI: Kontroll med trykte skrifter m. v.

Reglene tar sikte på å hindre misbruk av ytrings- og pressefriheten under krig og krigsfare.

Kapitlet inneholder en paragraf $-\S 33$ - som bl. a. gir adgang til a iverksette kontrolltiltak for å hindre at det utgis eller innf $\phi$ res skrifter som inneholder noe som kan skade forsvaret eller rikets forhold til fremmed stat eller true rikets indre eller ytre sikkerhet.

Under slike kontrolltiltak går også sensur. Grunnlovens § 100 forbyr forhåndssensur. Når det i utkastet likevel ble foreslått hjemmel for sensur, var det først og fremst med henblikk på at det under krig kan vise seg nødvendig å etablere militærsensur. ${ }^{17}$ ) I en slik situasjon antas Grunnlovens forbud å måtte vike etter prinsippene for konstitusjonell nødrett.

Bestemmelsene i § 33 går langt og har vakt kritikk. Når man skal vurdere dem, må man ha for $\phi y e$ at de — som lovutkastet ellers tar sikte på å møte de alvorligste av de eventualiteter som vil kunne inntre under krig 0.1 .

Det er imidlertid klart at skal man kunne få en kontrollordning som virker tilfredsstillende i praksis, trengs det et samarbeid mellom myndighetene og pressens folk. I de kontrollorganer som i tilfelle skal eta-

16) Om tilsvarende bestemmelser i Nederland, Sveits og Finnland henvises til fremstillingen i Ot.meld. nr. $1-1950$ s. 12,19 og $26-27$. Et nederlandsk forslag til lov om sivil unntakstilstand, som også inneholder regler om internering, er referert sammesteds s. 13-14.

${ }^{17}$ ) Militærsensur $i$ en eller annen form ble visstnok praktisert av alle de krigf $\varnothing$ rende land i $1940-45$. 
H. BAHR

bleres, må representanter for pressen være med. Det gjelder derfor å finne frem til en ordning som kan aksepteres også av pressens folk.

Etter proposisjonen var fremsatt, ble det f $\varnothing \mathrm{rt}$ forhandlinger om disse spørsmål mellom justisministeren og representanter for Norsk Presseforbund. Presseforbundet uttalte seg mot enhver form for forhåndssensur og foreslo i stedet opprettet et presseråd med sikte på å etablere et tillitsfullt samarbeid mellom myndigheter og presse for å verne om den sikkerhet myndighetene finner n $\varnothing$ dvendig under krig. Forbundet hevdet at avisene må beholde sin frihet til under ansvar å $\emptyset$ ve kritikk mot disposisjoner de finner uriktige,

Justisministeren erklærte seg villig til å sløyfe bestemmelsene om adgang til forhåndssensur, men antok at det $\mathrm{i}$ så fall ble nødvendig å skjerpe adgangen til å stanse aviser som overtrer gjeldende lover. Overfor tanken om et presseråd stilte justisministeren seg positivt. Han ga uttrykk for at ordningen - iallfall for tiden — ikke b $\phi r$ lovfestes, men søkes basert på frivillig samarbeid. Den bør ikke settes i verk før situasjonen er så kritisk at det blir nødvendig å sette i verk de andre tiltakene krigsloven tar sikte på. Den praktiske gennomf $\varnothing$ ring av ordningen og retningslinjene for rådets virksomhet forutsettes å bli gjenstand for videre forhandlinger mellom departementet og pressens organisasjoner.

Slik saken nå står, er det ikke grunn til å gå nærmere inn på for-slagets bestemmelser om pressekontroll. Men jeg nevner at bestemmelser om pressekontroll under krig, krigsfare og indre uroligheter ikke er ukjent $\mathrm{i}$ andre demokratiske land. Under siste krig var det således vidtgående lovbestemmelser om dette i de nøytrale land Sverige og Sveits. I Storbritannia gjaldt det under krigen bestemmelser som lå nær opp til de foreslåtte regler.

2. Lov om endring av lov om kontroll med post- og telegrafforsendelser av 24. juni 1915.

For å skape grunnlag for en mer effektiv sikrings- og overvåkningstjeneste allerede $\mathrm{i}$ fredstid foreslåes $\mathrm{i}$ proposisjonen en utvidelse av adgangen til kontroll med post- og telegrafforbindelser også i fredstid. Videre foreslåes loven endret slik at den vil gi uttrykkelig hjemmel for kontroll med telefonsamtaler.

IV.

Den offentlige diskusjon om forslaget til krigslov.

Det er få lovforslag som har satt sinnene slik i bevegelse som forslaget til krigslov. Så vidtgående som forslaget var, måtte en også regne med en kraftig reaksjon.

Forslaget har været behandlet $\mathrm{i}$ meget stort antall avisartikler og er blitt drøftet i foreningsm $\varnothing$ ter og i Kringkastingen. Som tidligere nevnt har debatten vesentlig vært konsentrert om vilkårene for å anvende 
loven, om forræderidomstolen, om sikringstiltak og om kontroll med trykte skrifter $\mathrm{m}$. $\mathrm{v}$.

I begynnelsen av oktober 1950 ble det sendt inn til Stortinget en skrivelse med protest mot de foreslătte bestemmelser om internering, pressesensur og «d $\varnothing$ dsstraff ved sivile standretter». Skrivelsen hadde 500 underskrifter, og blant underskriverne var mange kjente personligheter. Senere kom det flere protester. Justiskomitéen meddeler i sin innstilling at 85 foreninger og 7283 enkeltpersoner har protestert mot proposisjonen eller mot enkelte bestemmelser i den, mens 359 enkeltpersoner har gitt uttrykk for tilslutning til proposisjonen. Studentersamfunnet i Oslo vedtok en resolusjon mot forslaget, mens et tilsvarende resolusjonsforslag ble nedstemt i Studentersamfunnet i Bergen; ved landbrukshøgskolen på Ås ble vedtatt en resolusjon med tilslutning til proposisjonen.

Motstanderne av proposisjonen anførte bl. a. at den gav anvisning på autoritære metoder som er uforenelige med våre demokratiske prinsipper, at den var i strid med grunnloven, at den kunne misbrukes av en samvittighetsløs regjering til å innføre diktatur, og at den kunne utnyttes av en fremmed okkupasjonsmakt. Det ble også påstått at de foreslåtte bestemmelser savner sidestykke i andre demokratiske land. ${ }^{18}$ )

I argumentasjonen mot loven er det ofte blitt henvist til prinsippet om den konstitusjonelle n $\emptyset$ drett. Proposisjonens motstandere har hevdet at dette forfatningsrettslige prinsipp vil gi Regjeringen fullt tilstrekkelige fullmakter $\mathrm{i}$ en krigssituasjon, og at det vil gi muligheter for en langt mer smidig løsning av de problemer som måtte melde seg. I den forbindelse er fremholdt at vi jo ikke idag kan ha oversikt over alle de situasjoner som kan oppstå. Det kan i et gitt tilfelle vise seg at det trengs andre forholdsregler enn dem krigsloven gir anvisning på. Under slike omstendigheter kan loven bli en hemsko for myndighetene og gjøre mer skade enn gagn.

Blant dem som har angrepet forslaget, er det også en del som mener at det kan trengs unntaksbestemmelser i krig, og at loven derfor burde vedtas som en ren krigslov, men at den under ingen omstendigheter må kunne anvendes utenfor krig.

På den annen side var det også mange som gikk sterkt inn for forslaget. Men også fra folk som i prinsippet var enig i det, kom det atskillig kritikk mot enhelthetene $i$ forslaget. Det ble således hevdet at vilkårene for å anvende loven var for løst formulert, og at forslaget $i$ det hele ikke inneholdt tilstrekkelige garantier mot misbruk.

18) En samling avisartikler og andre innleg mot proposisjonen er utgitt under titelen »Front mot frykten «. Sakførerforeningen i Oslo har under titelen »Beredskapslovgivningen « gitt ut forhandlingene på et møte om saken med innledningsforedrag av justisminister Gundersen. Denne publikasjon inneholder også proposisjonens tekst. 
Det ville føre for langt her å ta opp til behandling alle de innvendinger som er fremsatt mot forslaget. Men jeg finner det på sin plass å gå litt inn på enkelte av de prinsipielle spørsmål.

Med hensyn til den innvending at forslaget er uforenelig med demokratiske prinsipper, skal jeg bemerke:

Vår demokratiske samfunnsordning er innrettet på fred. De demokratiske prinsipper om personlig ukrenkelighet, ytringsfrihet, pressefrihet osv. bør opprettholdes også i ufredstider. Men de kan under slike forhold ikke håndheves $\mathrm{i}$ sin ytterste konsekvens uten at det går ut over slagkraften i samfunnets forsvarsanstrengelser. Erfaring har vist at når et demokratisk samfunn kjemper for sin eksistens, kan det bli nødt til å slå av på sine prinsipper og anvende midler som det ikke ville benytte seg av under normale forhold, f. eks. internering. Det gjorde således England og andre demokratiske land under den siste krig. Men de sluttet med det igjen da krigen var over. En slik midlertidig avvikelse fra demokratiske prinsipper i en nødssituasjon betyr ikke at man oppgir selve prinsippene.

Når det gjelder forholdet til Grunnloven, må forslaget sees på bakgrunn av prinsippet om den konstitusjonelle nødrett. ${ }^{19}$ ) Vilkårene for å anvende loven er formet nettopp med henblikk på situasjoner hvor Regjeringen kan fravike Grunnlovens bud i henhold til konstitusjonell n $\varnothing$ drett. Og de tiltak forslaget handler om ligger etter min mening ikke utenfor det som regjeringen i en slik situasjon kunne bestemme i kraft av nødrett.

Spørsmålet om forslagets forhold til Grunnloven har særlig vært fremme $\mathrm{i}$ forbindelse med bestemmelsene om forvaring og pressekontroll.

Det spørsmål har vært reist om ikke de foreslåtte regler, særlig reglene om Kongens ekstraordinære fullmakter, rettest burde gis i form av grunnlovsbestemmelse. Jeg går ikke nærmere inn på spørsmålet, men nevner bare at det under de nåværende forhold ville være forbundet med betydelig risiko å vente til forslaget kunne bli fremmet og vedtatt på den måte som er foreskrevet for grunnlovendringer.

Hvad angår faren for misbruk, har diskusjonen særlig dreiet seg om vilkårene for å sette loven i kraft utenfor krig. Opposisjonen har hevdet at disse vilkår er alt for løst formulert. Spesielt har den rettet sterke angrep mot det tredje vilkår: «når rikets selvstendighet eller sikkerhet er i fare som følge av pågånende eller truende fiendtligheter mellom fremmede stater eller av andre grunner.»

Noen av proposisjonens motstandere har påstått at det tredje vilkår ville gi Regjeringen frie hender til å sette loven i kraft når den

19) Reglene om den konstitusjonelle nødrett er behandlet av professtor Frede Castberg i Norges Statsforfatning (2. utg.) II s. 493-506 og Fra norsk og fremmed statsliv (1946) s. 17-28. Se nå også professorene Castberg og Andenæs i Dok. nr. 11 for 1950. 
finner for godt. De leser m. a. o. forslaget som om vilkårene for å anvende loven var enten krig, krigstrussel eller «andre grunner». Dette er en åpenbar misforståelse.

Den viktigste garanti mot misbruk lå imidlertid ikke $i$ formuleringen av vilkårene for å anvende loven, men i reglene om fremgangsmåten. Som tidligere nevnt gikk forslaget her ut på at loven utenfor krig bare kan anvendes etter særskilt vedtak av Kongen, og slikt vedtak kan han normalt bare gjøre når Stortinget på forhånd har samtykket i det. Er Stortinget ikke samlet, vil det være Kongens plikt å kalle det inn til ekstraordinær sesjon for at det kan ta standpunkt til spørsmålet. Bare hvis situasjonen er så kritisk at det ikke er tid til dette, kan Kongen sette loven i kraft på egen hånd.

Mot det standpunkt at nфdrettsinstituttet vil være tilstrekkelig som retsgrunnlag for de ekstraordinære tiltak som måtte trenges, og at det vil gi bedre resultater enn lovbestemmelser vedtatt på forhånd, kan det etter min mening rettes tungtveiende innvendinger. Først og fremst den at en lov er nødvendig som grunnlag for de forberedelser myndighetene må treffe med henblikk på krig og krigsfare. ${ }^{20}$ ) Det er også vanskelig å forstå at det fra et demokratisk synspunkt skulle være bedre å gi Regjeringen frie hender til å handle i en nødssituasjon enn å fastsette dens myndighet på forhånd.

Jeg har nevnt at det fra enkelte hold har vært hevdet at loven bør begrenses til bare å gjelde i krig. En slik begrensning ville bety et vesentlig skår i lovens effektivitet. Det kan være like nødvendig eller kanskje enda mer nødvendig - å bekjempe femtekolonnevirksomhet $\mathrm{i}$ de kritiske dagene f $\varnothing \mathrm{r}$ et krigsutbrudd som etter at krigen er begynt. I Ot. meld. nr. 1 er det tatt inn uttalelser fra politimesteren i Oslo og sjefen for Forsvarsstaben om dette spørsmål. Begge fraråder en begrensning som nevnt.

Påstanden om at loven savner sidestykke $i$ andre demokratiske land, er fullstendig uholdbar. Slike lover er på ingen måte noe særsyn i den demokratiske verden. Jeg nфyer meg med å vise til oversikten i Ot. meld. nr. 1.

V.

Krigslovens behandling i justiskomité og Storting.

Resultatet av behandlingen i Stortingets justiskomité ble et utpreget kompromiss. Bestemmelsene om forræderidomstol, internering og pressekontroll gikk ut av loven, mens de generelle fullmakter til Kongen blev vedtatt. Samtidig uttalte komitéen i sin premisser:

«Heri ligger dog ikke at en tar avstand fra at tiltak av denne art settes $\mathrm{i}$ verk når situasjonen gjør det absolutt n $\phi$ dvendig. Tvertom. Det er statsmyndighetenes plikt til enhver tid å være forberedt på at

20) Jfr. i denne forbindelse en uttalelse fra sjefen for Forsvarsstaben, som er inntatt i Ot.meld. nr. 1 s. 35 flg. 
vårt land når som helst kan stilles overfor krig og krisesituasjoner og ha sine motforholdsregler klare. En forutsetter at forslag og tiltak blir forberedt på en slik måte at de kan settes i verk hvis situasjonen krever det, og at Regjeringen orienterer de administrative tjenestemenn om forberedelsene $\mathrm{i}$ den utstrekning det anses n $\varnothing$ dvendig. Men det storting eller den regjering som setter tiltakene ut i livet, må selv vurdere om det, sett på bakgrunn av den foreliggende situasjon, er forfatningsmessig adgang til det.«

Premissene for justiskomitéens forslag gir altså en godkjenning i prinsippet også av slike tiltak som diskusjonen hadde stått om. Det ble opplyst under debatten i Stortinget at utformingen av forslaget hadde funnet sted $\mathrm{i}$ forhandling med justisministeren, som st $\varnothing$ ttet det forslag komitéen kom frem til.

Omfanget av regjeringens fullmakter er forskjellige ettersom Stortinget på grunn av krig er avskåret fra å utøve sin virksomhet (kap. I i loven) eller dette ikke er tilfellet (kap. II i loven).

Er Stortinget på grunn av krig avskåret fra å utøve sin virksomhet, tilligger det etter lovforslaget Kongen å «gjøre alle de vedtak som er påkrevd for å vareta rikets interesser under krigen og forberede overgangen til fredelige forhold.» Denne bestemmelse er gått uforandret over fra proposisjonen. Den tar, som det blir fremhevet $\mathrm{i}$ innstillingen, sikte på å gi uttrykk for det samme prinsipp som Elverumsfullmakten av 9. april 1940. En har jo ingen garanti for at det ved et lynangrep blir anledning til å få samlet Stortinget, slik som det kunne skje ved det tyske overfall.

Fra strengt juridisk synspunkt kan det sies at en slik bestemmelse er overflødig. Når Stortinget er satt ut av spillet, følger det av forfatningens system at Kongen, som det handledyktige statsorgan, må overta varetagelsen av statens interesser, også i den utstrekning det blir nødvendig med myndighetsut $\varnothing$ velse som normalt ligger under Stortinget. Betydningen av bestemmelsen ligger derfor, som det er blitt sagt, mer på det politiske og psykologiske plan enn på det juridiske. Justiskomitéen peker spesielt på den betydning det kan ha overfor utlandet at Regjeringen har en uttrykkelig fullmakt fra Stortinget å vise til. Det er visst ingen tvil om at Elverumsfullmakten under siste krig betød en mektig styrkelse av regeringens stilling utad.

Innstillingen gir imidlertid Kongen ekstraordinære fullmakter også utenfor det tilfelle at Stortinget er avskåret fra å utøve sin virksomhet. Lovens $\& 3$ bestemmer herom:

Når riket er i krig eller krig truer eller rikets selvstendighet eller sikkerhet er i fare og det på grunn av disse forhold er fare ved opphold, kan Kongen gi bestemmelser av lovgivningsmessig innhold for à trygge rikets sikkerhet, den offentlige orden, folkehelsen og landets forsyninger, for å fremme og trygge militære tiltak og tiltak til vern om sivilbefolkning og eiendom og for å utnytte landets hjelpekilder til fremme av disse formål. Herunder kan gis bestemmelser om utskriving av arbeidskraft til militære og sivile formål. Om nødvendig kan det $\mathrm{i}$ bestemmelsene gjøres avvik fra gjeldende lov. 
Bestemmelser gitt av Kongen med hjemmel i denne paragraf skal snarest mulig meddeles Stortinget. Er Stortinget ikke samlet når bestemmelsene gis, skal det $\phi y$ eblikkelig sammenkalles. Bestemmelsene kan oppheves av Kongen eller Stortinget.

Hvis bestemmelsene ikke er opphevet innen 30 dager etter at de er meddelt Stortinget, skal de snarest mulig legges fram som lovforslag.

Også dette stemmer $\mathrm{i}$ alt vesentlig med proposisjonen, selv om den formelle oppbygning av bestemmelsene er en annen. Komitéen har ikke bøyd seg for kritikken mot det «tredje vilkår» for lovens anvendelse (at rikets sikkerhet eller selvstendighet er i fare). Komitéen har ikke funnet å kunne se bort fra de betraktninger som er anført av Forsvarsdepartementet og Utenriksdepartementet, at det $i$ en spent situasjon kan få farlige følger om man offisielt gir uttryk for at man føler seg truet eller frykter intervensjon fra en fremmed stat. Men komitéen understreker at lovens fullmaktsbestemmelser ikke kan anvendes om man kommer opp i uroligheter og alvorlige vanskeligheter av rent indre art, f. eks. omfattende ulovlige streikeaksjoner.

Formelt sett står regjeringen friere etter loven enn etter proposisjonen, idet den ved anvendelsen av fullmaktene ikke er bundet av de særlige kauteler som i proposisjonen var bygget opp omkring bestemmelsene om forræderidomstol, internering og pressekontroll. Justiskomitéen fremhever imidlertid det psykologiske moment, at hvis man, slik som det var foreslått i proposisjonen, vedtar lovregler f. eks. om internering og pressesensur som et permanent ledd i vår lovgivning, kan dette f $\varnothing \mathrm{re}$ til at inngrepene $i$ den alminnelige bevissthet vil tape noe av sin ekstraordinære karakter, slik at motviljen mot inngrep av denne art vil kunne svekkes, og misbruk derfor lettere kunne tenkes.

I den kommunistiske presse ble justiskomitéens innstilling karakterisert som en tynn kamuflasje med det formål å bedra og villede folkeopinionen, og også enkelte andre blant proposisjonens motstandere slo på de samme strenger. Andre motstandere hilste derimot innstillingen med tilfredshet, fordi den i deres $\varnothing$ yne fjernet de største anst $\varnothing$ tsstener. Og da saken kom til behandling i Stortinget, ble innstillingen vedtatt med overveldende flertall. Et utsettelsesforslag samlet bare 11 stemmer i Odelstinget, de fleste fra Bondepartiet.

H. Bahr. 